\title{
Erratum to: Environmental assessment of sardine (Sardina pilchardus ) purse seine fishery in Portugal with LCA methodology including biological impact categories
}

\author{
Cheila Almeida • Sofia Vaz • Henrique Cabral • \\ Friederike Ziegler
}

Published online: 24 October 2013

(C) Springer-Verlag Berlin Heidelberg 2013

\section{Erratum to: Int J Life Cycle Assess \\ DOI 10.1007/s11367-013-0646-5}

Page 4 of online version (changes are in boldface)

Old:

The FUI per sardine landed was neither statistically different between years nor between vessel size categories ( $t$ test, $p=$ $0.35)$. Average values for the different years assessed varied between $0.9(\mathrm{SD}=0.02)$ and $0.14(\mathrm{SD}=0.03) 1 / \mathrm{kg}$ and the fuel consumption use was highest in 2008, coinciding with the year for the largest landings of large purse seiners (Fig. 2).

New:

The FUI per sardine landed was neither statistically different between years nor between vessel size categories ( $t$ test, $p=$ $0.35)$. Average values for the different years assessed varied between $0.09(\mathrm{SD}=0.02)$ and $0.14(\mathrm{SD}=0.03) 1 / \mathrm{kg}$ and the fuel consumption use was highest in 2008, coinciding with the year for the largest landings of large purse seiners (Fig. 2).

Old:

The average global warming potential (GWP) for the overall fleet was $0.36 \mathrm{~kg} \mathrm{CO} 2 \mathrm{eq}$. The GWP for the

The online version of the original article can be found at http://dx.doi.org/ 10.1007/s11367-013-0646-5.

\section{Almeida $\cdot$ H. Cabral}

Centro de Oceanografia, Faculdade de Ciências, Universidade de

Lisboa, Lisboa, Portugal

C. Almeida $\cdot$ S. Vaz

Centre for Environmental and Sustainability Research, Faculdade de Ciências de Tecnologia, Universidade Nova de Lisboa, Lisbon, Portugal

C. Almeida $(\bowtie) \cdot$ F. Ziegler

The Swedish Institute for Food and Biotechnology, 40229 Gothenburg, Sweden

e-mail: cpa@sik.se two size vessel categories were almost equal: 0.35 for larger and $0.36 \mathrm{~kg} . \mathrm{CO} 2 \mathrm{eq}$ for smaller boats. The same trend happens with the other impact categories due to the dominance of fuel combustion and production. For the categories EP, AP, and ODP the results for the overall fleet were $0.0024 \mathrm{~kg} \mathrm{SO} 2$ eq; $0.0005 \mathrm{~kg} \mathrm{PO} 4 \mathrm{eq}$; and $0.48 \mathrm{~kg}$ CFC-11 eq, respectively.

New:

The average global warming potential (GWP) for the overall fleet was $0.36 \mathrm{~kg} \mathrm{CO} 2$ eq. The GWP for the two size vessel categories were almost equal: 0.35 for larger and $0.36 \mathrm{~kg} . \mathrm{CO} 2$ eq for smaller boats. The same trend happens with the other impact categories due to the dominance of fuel combustion and production. For the categories EP, AP, and ODP the results for the overall fleet were $0.0024 \mathrm{~kg} \mathrm{SO} 2$ eq;0.0005 kg PO4 eq; and 4.77E-08 kg CFC-11 eq, respectively.

Page 8 on online version: Table 2 (changes are in boldface)

Table 2 Data from JRC for purse seine fishery in Portugal

\begin{tabular}{lccc}
\hline Size & 2008 & 2009 & 2010 \\
\hline Fuel per landings (1/kg) & & & \\
Small & 0.09 & 0.13 & 0.15 \\
Large & 0.11 & 0.12 & 0.13 \\
Overall & 0.11 & 0.12 & 0.13 \\
Labour per landings (crew/tonne) & & \\
Small & $\mathbf{0 . 1 3}$ & $\mathbf{0 . 1 1}$ & $\mathbf{0 . 0 9}$ \\
Large & $\mathbf{0 . 0 2}$ & $\mathbf{0 . 0 2}$ & $\mathbf{0 . 0 2}$ \\
Overall & $\mathbf{0 . 0 3}$ & $\mathbf{0 . 0 3}$ & $\mathbf{0 . 0 3}$ \\
Value per landings (EUR/tonne) & & \\
Small & $\mathbf{1 . 2 0}$ & $\mathbf{1 . 0 7}$ & $\mathbf{0 . 9 2}$ \\
Large & $\mathbf{0 . 6 3}$ & $\mathbf{0 . 7 0}$ & $\mathbf{0 . 1 4}$ \\
Overall & $\mathbf{0 . 6 6}$ & $\mathbf{0 . 7 4}$ & $\mathbf{0 . 6 0}$ \\
\hline
\end{tabular}




\section{Online Resource (changes are in boldface)}

Old: Table 1 Inventory for fish landed in Portugal by purse seiners. Values per FU (standard deviation) of fish landed for the overall fleet and for different vessel size categories in the 2006-2011 period. Data is referred to the selected FU in the study (1 kg of landed fish).

\begin{tabular}{|c|c|c|c|c|c|c|c|}
\hline Inputs & Unit & 2006 & 2007 & 2008 & 2009 & 2010 & 2011 \\
\hline Diesel & 1 & $0.03(0,09)$ & $0.00(0,11)$ & $0.02(0,14)$ & $0.03(0,12)$ & $0.03(0,09)$ & $0.02(0,10)$ \\
\hline Ice & $\mathrm{kg}$ & $0.02(0,11)$ & $0.02(0,08)$ & $0.04(0,12)$ & $0.05(0,12)$ & $0.05(0,15)$ & $0.05(0,18)$ \\
\hline Marine lubricant oil & 1 & $0.00(0,00)$ & $0.00(0,00)$ & $0.01(0,01)$ & $0.02(0,01)$ & $0.01(0,01)$ & $0.01(0,00)$ \\
\hline \multicolumn{8}{|l|}{ Outputs } \\
\hline Sardine & $\mathrm{kg}$ & $0.70(0,91)$ & $0.89(0,89)$ & $0.90(0,91)$ & $0.88(0,94)$ & $0.95(0,89)$ & $0.93(0,85)$ \\
\hline Other species & $\mathrm{kg}$ & $0.30(0,09)$ & $0.11(0,11)$ & $0.10(0,09)$ & $0.12(0,06)$ & $0.05(0,11)$ & $0.07(0,15)$ \\
\hline $\mathrm{CO} 2$ & $\mathrm{~kg}$ & 0.292 & 0.363 & 0.466 & 0.398 & 0.301 & 0.318 \\
\hline $\mathrm{SO} 2$ & g & 0.430 & 0.523 & 0.662 & 0.569 & 0.438 & 0.461 \\
\hline $\mathrm{NOx}$ & $\mathrm{kg}$ & 0.003 & 0.004 & 0.005 & 0.004 & 0.003 & 0.003 \\
\hline \multicolumn{8}{|l|}{ Impact assessment } \\
\hline GWP & $\mathrm{kg} \mathrm{CO} 2 \mathrm{eq}$ & 0.292 & 0.363 & 0.466 & 0.398 & 0.301 & 0.318 \\
\hline EP & $\mathrm{kg}$ PO4 eq & 0.000 & 0.001 & 0.001 & 0.001 & 0.000 & 0.000 \\
\hline $\mathrm{AP}$ & $\mathrm{kg} \mathrm{SO} 2 \mathrm{eq}$ & 0.002 & 0.002 & 0.003 & 0.003 & 0.002 & 0.002 \\
\hline ODP & kg CFC-11 eq & 0.385 & 0.475 & 0.604 & 0.518 & 0.397 & 0.418 \\
\hline $\mathrm{E}$ & $\mathrm{MJ}$ & 4.330 & 5.390 & 6.910 & 5.900 & 4.470 & 4.720 \\
\hline
\end{tabular}

New: Table 1 Inventory for fish landed in Portugal by purse seiners. Values per FU (standard deviation) of fish landed for the overall fleet and for different vessel size categories in the 2006-2011 period. Data is referred to the selected FU in the study (1 kg of landed fish).

\begin{tabular}{|c|c|c|c|c|c|c|c|}
\hline Inputs & Unit & 2006 & 2007 & 2008 & 2009 & 2010 & 2011 \\
\hline Diesel & 1 & $0.03(0,09)$ & $0.00(0,11)$ & $0.02(0,14)$ & $0.03(0,12)$ & $0.03(0,09)$ & $0.02(0,10)$ \\
\hline Ice & $\mathrm{kg}$ & $0.02(0,11)$ & $0.02(0,08)$ & $0.04(0,12)$ & $0.05(0,12)$ & $0.05(0,15)$ & $0.05(0,18)$ \\
\hline Marine lubricant oil & 1 & $0.00(0,00)$ & $0.00(0,00)$ & $0.01(0,01)$ & $0.02(0,01)$ & $0.01(0,01)$ & $0.01(0,00)$ \\
\hline \multicolumn{8}{|l|}{ Outputs } \\
\hline Sardine & $\mathrm{kg}$ & $0.70(0,91)$ & $0.89(0,89)$ & $0.90(0,91)$ & $0.88(0,94)$ & $0.95(0,89)$ & $0.93(0,85)$ \\
\hline Other species & $\mathrm{kg}$ & $0.30(0,09)$ & $0.11(0,11)$ & $0.10(0,09)$ & $0.12(0,06)$ & $0.05(0,11)$ & $0.07(0,15)$ \\
\hline $\mathrm{CO} 2$ & $\mathrm{~kg}$ & 0.292 & 0.363 & 0.466 & 0.398 & 0.301 & 0.318 \\
\hline $\mathrm{SO} 2$ & $\mathrm{~g}$ & 0.430 & 0.523 & 0.662 & 0.569 & 0.438 & 0.461 \\
\hline NOx & $\mathrm{kg}$ & 0.003 & 0.004 & 0.005 & 0.004 & 0.003 & 0.003 \\
\hline \multicolumn{8}{|l|}{ Impact assessment } \\
\hline GWP & $\mathrm{kg} \mathrm{CO} 2 \mathrm{eq}$ & 0.292 & 0.363 & 0.466 & 0.397 & 0.301 & 0.318 \\
\hline EP & kg PO4 eq & 0.000 & 0.001 & 0.001 & 0.001 & 0.000 & 0.000 \\
\hline $\mathrm{AP}$ & $\mathrm{kg} \mathrm{SO} 2 \mathrm{eq}$ & 0.002 & 0.002 & 0.003 & 0.003 & 0.002 & 0.002 \\
\hline ODP & kg CFC-11 eq & $3.86 \mathrm{E}-08$ & 4.75E- 08 & $6.04 \mathrm{E}-08$ & 5.18E-08 & 3.97E-08 & 4.18E-08 \\
\hline $\mathrm{E}$ & MJ & 4.330 & 5.390 & 6.910 & 5.900 & 4.470 & 4.720 \\
\hline
\end{tabular}

